\author{
Gaël Lebon, Marine Rondeau, Lisa \\ Sanchez, Essaid Ait Barka, Nathalie \\ Vaillant-Gaveau, Christophe Clément \\ and Cédric Jacquard ${ }^{\star}$
}

Université de Reims Champagne-Ardenne, UFR Sciences Exactes et Naturelles, SFR Condorcet FR CNRS 3417, Unité de Recherche Vignes et Vins de Champagne - EA 4707, BP 1039, 51687 Reims Cedex 2, France

Dates: Received: 23 September, 2016; Accepted: 13 October, 2016;Published: 14 October, 2016

${ }^{*}$ Corresponding author: Cédric Jacquard Université de Reims Champagne-Ardenne, UFR Sciences Exactes et Naturelles, SFR Condorcet FR CNRS 3417, Unité de Recherche Vignes et Vins de Champagne - EA 4707, BP 1039, 51687 Reims Cedex 2, France, Tel: +33 326913 436; Fax: +33 326913 427; E-mail: cedric.jacquard@univ-reims.fr www.peertechz.com

Keywords: Carbohydrate metabolism; Enzyme activities; Grapevine; Inflorescences; Starch; Sucrose ISSN: 2640-7906

\author{
Research Article
}

\section{Modulation of the Activity of} Enzymes Involved in Carbohydrate Metabolism during Flower Development of Grapevine (Vitis Vinifera L.)

\section{Abbreviations}

$\alpha \mathrm{A}$ : alpha A; $\beta \mathrm{A}$ : beta Amylase; $\mathrm{BBCH}$ : Biologische Bundesanstalt, Bundessortenamt and CHemical industry; Cy Inv: Cytosolic Invertase; DS: Developmental Stages; DW: Dry Weight; GW: Gewurztraminer; PN: Pinot Noir; SPS: Sucrose-Phosphate Synthase; SSd: Sucrose Synthase (degradation); SSs: Sucrose Synthase (synthesis); StSy: Starch Synthase; WB Inv: Wall-Bound invertase.

\section{Introduction}

Grapevine (Vitis vinifera L.) is naturally affected by the flower abscission depending on both physiological factors such as the carbon nutrition [1] and cultivars [2], and environmental factors [3] such as chilling or heat [4-7]. Under optimal growth conditions, the intensity of flower drop represents a specific trait of each cultivar (cv.). For instance, in the Gewurztraminer (GW) cv., flower drop corresponds to $18 \%$ of the total flowers whereas in the Pinot noir (PN) cv., the abscission of flowers reaches $35 \%[1,8]$. However, when environmental stress occurs, the rate of flower abscission may change dramatically, reaching up to $80 \%$ in the $\mathrm{GW} \mathrm{cv}$. [2]. In this respect, the various cultivars (cvs.) of grapevine can be classified into two types according to their sensitivity to the flower drop under stressing conditions: (i) sensitive cvs. Such as GW, and (ii) non-sensitive cvs. Such as PN.

Under optimal growth conditions, the rate of flower abscission is correlated with the pathway of both male and female organ development and to the amount of carbohydrates in the inflorescences $[3,9]$. Comparing GW and PN, it was shown that the development of reproductive structures in PN is earlier than in GW [1]. Moreover, gametophyte development is dependent on sugar physiology, and any perturbation in carbohydrate metabolism during flower development induces the gametophyte abortion [10,11], leading to reduce the success of fertilization $[12,13]$. In particular, the reproductive organs are sensitive to modifications of carbohydrate physiology when fertile tissues reach meiosis [11]. At this key step, the rate of fertilization depends on the cultivars and can be correlated to the carbohydrate status of grapevine inflorescence [1].

The pathway of sugar fluctuations in woody plant organs is the result of complex regulation processes involving photosynthesis [14$16]$ and reserve mobilization/restoration $[17,18]$. Carbon assimilated in photosynthetic leaves is translocated as sucrose to sink organs, where it is converted into glucose and fructose or stored as starch reserves. Most often, the control of carbohydrate variations is reliable with feedback regulation of photosynthesis by carbon metabolites $[19,20]$, affecting the related enzyme activities [21-23]. In the developing inflorescence of grapevine, it was shown that carbohydrates are supplied by reserve mobilization from perennial organs [17] and by photosynthesis in both leaves [24] and inflorescences [25-27].

Starch is of great importance as sugar nutrient reserve in the developing flowers $[28,29]$. Starch-degrading enzymes in plant tissues include two kinds of amylases [30]. The alpha-amylase [aA 
- EC 3.2.1.1] is an endo-enzyme cutting randomly amylose and amylopectin chains into dextrins [31]. In parallel, the beta-amylase [ $\beta \mathrm{A} \mathrm{A}-\mathrm{EC}$ 3.2.1.2] is an exo-enzyme that releases molecules of maltose from amylose chains [32]. These two enzymes reflect distinct modes of starch mobilization and may represent a potential marker among the various cultivars. Other enzymes involved in starch biosynthesis are starch synthase [StSy - EC 2.4.1.21], which synthetises amylose by reaction with ADPGlc and starch branching enzyme [EC 2.4.1.18] for the synthesis of amylopectin by reacting with the amylose chains $[33,34]$.

The inflorescence is the plant organ containing the highest concentration of soluble sugars during its development and sucrose represents the main form of circulating sugar [35,36], namely in young grapevine inflorescences at key developmental steps [1]. Three enzymes are directly involved in sucrose metabolism [29]: (i) the sucrose phosphate synthase [SPS - EC 2.4.1.14], which plays a major role in sucrose biosynthesis [37]; (ii) the sucrose synthase [SS - EC 2.4.1.13] that catalyses the reversible conversion of sucrose and UDP into fructose and UDP-glucose $[22,38]$; and (iii) the invertase [Inv EC 3.2.1.26], which is an hydrolase, cleaving sucrose irreversibly into glucose and fructose $[22,38]$. Several Inv isoforms either cytoplasmic (Cy Inv) or wall-bounded (WB Inv) have been described in flower organs [39], pointing different sucrose utilization pathways as well. In addition to these three enzymes, SS is also considered to assume a sucrose synthesis in some plant tissues [40].

In order to further understand the relationships between flower development and sugar metabolism in grapevine, we assayed relatedenzymes activity in the inflorescences accurately from the appearance of flower buds until the fruit set. In this aim, we used the GW and the PN cvs., differing in their sensitivity to flower abscission. We focused on the meiosis step, which was shown to be a crucial point for the achievement of sexual plant reproduction and reflecting major differences in sugar physiology in the two cultivars [1,41]. Further, we particularly focused on the enzymes involved in the synthesis and degradation of both starch and sucrose since they are the major sugars in the inflorescences of grapevine during the flower development [42].

\section{Materials and Methods}

\section{Plant material and sampling}

Thirty-year-old field-grown grapevines (Vitis vinifera L.) GW (flower abscission sensitive) cv. (clone 47) and PN (non-sensitive) cv. (clone 162) were grown in Bergheim (France) following similar cultural practices. Development stages were identified according to the $\mathrm{BBCH}$ (Biologische Bundesanstalt, Bundessortenamt and CHemical industry) scale [43]. Inflorescences were investigated during their whole development, from the "visible cluster" stage (BBCH53) up to fruit set (BBCH71). For further precision, especially at the key step meiosis, 2 additional stages were added between the "separated cluster" stage (BBCH55) and the "separated floral buds" stage (BBCH57): 2 and 8 days after $\mathrm{BBCH} 55$ corresponding to female meiosis in PN and GW respectively [1]. Inflorescences were collected at the same hour during the day to avoid circadian fluctuations according to eight development stages (DS) as follows:

\begin{tabular}{|l|l|}
\hline Development stage in BBCH scale & Abbreviation \\
\hline BBCH 53 (visible cluster) & DS1 \\
\hline BBCH 55 (separated cluster) & DS2 \\
\hline BBCH $55+2$ d (2 days after separated cluster) & DS3 \\
\hline BBCH $55+8 d$ (8 days after separated cluster) & DS4 \\
\hline BBCH 57 (flower separating) & DS5 \\
\hline BBCH 60 (first detached floral caps) & DS6 \\
\hline BBCH 68 (80\% fallen flowerhoods) & DS7 \\
\hline BBCH 71 (fruit set) & DS8 \\
\hline
\end{tabular}

Inflorescences were collected at each DS, frozen in liquid N2 and stored at $-80^{\circ} \mathrm{Cuntil}$ sugar or enzyme extraction and activity determination.

\section{Carbohydrate extraction}

Lyophilized inflorescences were ground in a mortar with Fontainebleau sand and 10 volumes of ethanol $80^{\circ}$. Sugars were then extracted for $15 \mathrm{~min}$ at $84^{\circ} \mathrm{C}$ under continual agitation. After adjusting the volume to $5 \mathrm{~mL}$ with distilled water, the extract was centrifuged at $4^{\circ} \mathrm{C}$ for $10 \mathrm{~min}$ at $11,000 \mathrm{~g}$. The supernatant was used for soluble sugar determination. For starch, the pellet previously obtained was suspended in a mixture containing dimethylsulfoxide: hydrochloric acid $8 \mathrm{~N}(8: 2)$ and starch was dissolved during $30 \mathrm{~min}$ at $60^{\circ} \mathrm{C}$ under continual agitation. After cooling, the extract was centrifuged at $20^{\circ} \mathrm{C}$ for $10 \mathrm{~min}$ at $13,000 \mathrm{~g}$ and the supernatant was kept at $-80^{\circ} \mathrm{C}$ until use.

\section{Sucrose assay [44]}

Sucrose was hydrolyzed to D-glucose and D-fructose in the presence of a $\beta$-fructosidase. D-glucose was phosphorylated and oxidized in the presence of NADP to gluconate-6-phosphate and $\mathrm{NADPH}, \mathrm{H}^{+}$. The amount of $\mathrm{NADPH}, \mathrm{H}^{+}$formed was determined by means of its absorbance at $340 \mathrm{~nm}$. D-glucose formed was then determined as described above and compared with a blank without $\beta$-fructosidase.

\section{Starch assay}

Aliquots of $100 \mu \mathrm{L}$ of the extract were used to determine starch concentration. The aliquot was mixed with $100 \mu \mathrm{L}$ of Lugol iodine solution (38.3 $\mathrm{mM} \mathrm{KI}$ and $2.8 \mathrm{mM} \mathrm{I} 2$ in $0.25 \mathrm{M} \mathrm{HCl})$. After $15 \mathrm{~min}$, the absorbance was read spectrophotometrically at $620 \mathrm{~nm}$. A blank was performed with the starch solvent (DMSO: $\mathrm{HCl}, 8: 2$ ) instead of the extract. Preparation of enzyme extract each protocol was performed at $0-4^{\circ} \mathrm{C}$ according to modified procedures from Nakamura and Yuki [21]. The inflorescences were ground and $500 \mathrm{mg}$ were homogenized with $5 \mathrm{~mL}$ of chilled buffer containing $100 \mathrm{mM}$ Tris-Hcl (pH 6.5), $8 \mathrm{mM} \mathrm{MgCl}$, $2 \mathrm{mM}$ EDTA, $1 \mathrm{mM}$ DTT and $0.1 \mathrm{mM}$ PMSF. The homogenate was transferred to Eppendorf tubes and centrifuged for $5 \mathrm{~min}$ at $14,000 \mathrm{~g}$ at $4^{\circ} \mathrm{C}$. The supernatant was collected, stored at $-80^{\circ} \mathrm{C}$ and used as enzyme source. The pellet was washed twice, suspended with the grinding solution and used for the assay of wall-bound invertase. Protein concentration in each sample was determined using a Bio-Rad DC protein assay kit (Bio-Rad, Hercules, CA, USA) and BSA as standard. 


\section{Enzyme assays}

Assays were carried out in the range of enzyme concentrations where the activity increased linearly with time and substrate concentration.

\section{Starch synthesis}

Starch synthase (StSy - EC 2.4.1.21) - The assay was conducted according to the modified protocol of Nakamura et al. [45]. An aliquot of $50 \mu \mathrm{L}$ of the enzyme extract was mixed to $230 \mu \mathrm{L}$ of $1.6 \mathrm{mM}$ ADP-glucose, $0.7 \mathrm{mg}$ amylopectin and $15 \mathrm{mM}$ DTT preparing in $50 \mathrm{mM}$ HEPES-NaOH at $\mathrm{pH}$ 7.4. After $20 \mathrm{~min}$ of incubation at $30^{\circ} \mathrm{C}$, the enzyme was inactivated by placing the mixture in a boiling-water bath for $30 \mathrm{sec}$. Then $100 \mu \mathrm{L}$ of a $50 \mathrm{mM}$ HEPES-NaOH pH 7.4 buffer, containing $4 \mathrm{mM} \mathrm{PEP}, 200 \mathrm{mM} \mathrm{KCl}, 10 \mathrm{mM} \mathrm{MgCl}$, and pyruvate kinase (1.2 unit) were added and the reaction mixture was incubated for $30 \mathrm{~min}$ at $30^{\circ} \mathrm{C}$. The ADP produced by the starch synthase reaction was converted to ATP and the resulting solution was heated in a boiling-water bath for $30 \mathrm{sec}$ and then subjected to centrifugation for $5 \mathrm{~min}$ at $10,000 \mathrm{~g}$. The supernatant $(300 \mu \mathrm{L})$ was mixed to $300 \mu \mathrm{L}$

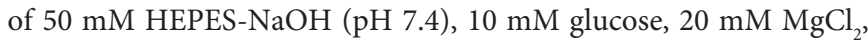
and $2 \mathrm{mM}$ NADP. The starch synthase activity was determined as the increase of absorbance at $340 \mathrm{~nm}$ after the addition of $1 \mu \mathrm{L}$ each of hexokinase (1.4 units) and G6P dehydrogenase ( 0.35 unit). Data were displayed in $\mu \mathrm{g}$ formed starch per $\mathrm{mg}$ of proteins per hour.

\section{Starch degradation}

Alpha amylase ( $\alpha \mathrm{A}$ - EC 3.2.1.1) - To estimate this activity, the $\alpha$-amylase enzyme was first inactivated by heating $1 \mathrm{~mL}$ of enzyme source for $15 \mathrm{~min}$ at $70^{\circ} \mathrm{C}$ [46]. After centrifugation at 10,000g for $15 \mathrm{~min}, 100 \mu \mathrm{L}$ of supernatant were added to $200 \mu \mathrm{L}$ of substrate ( $0.15 \%$ starch, $20 \mathrm{mM} \mathrm{CaCl}_{2}$, and $50 \mathrm{mM} \mathrm{NaCl}$ prepared in $50 \mathrm{mM}$ sodium acetate buffer at $\mathrm{pH} 4.8$ ). The mixture was incubated for $60 \mathrm{~min}$ at $37^{\circ} \mathrm{C}$ and the reaction stopped by addition of $800 \mu \mathrm{L}$ of an iodine solution ( $38.3 \mathrm{mM} \mathrm{KI}$ and $2.8 \mathrm{mM} \mathrm{I}_{2}$ in $0.25 \mathrm{M} \mathrm{HCl}$ ) and $3.2 \mathrm{~mL}$ of $\mathrm{dH}_{2} \mathrm{O}$. The residual starch content was then determined spectrophotometrically at $620 \mathrm{~nm}$. Data were expressed in $\mu \mathrm{g}$ of hydrolyzed starch per mg of proteins per hour.

Beta amylase ( $\beta \mathrm{A}$ - EC 3.2.1.2) - Estimation of the $\beta$-amylase activity was performed at $\mathrm{pH} 3.6$ in order to inhibit the $\beta$-amylase [47]. An aliquot of $200 \mu \mathrm{L}$ of the enzyme extract was incubated for $60 \mathrm{~min}$ at $20^{\circ} \mathrm{C}$ in $200 \mu \mathrm{L}$ of $1 \%$ starch and $0.78 \mathrm{mM}$ ethylenediaminetetraacetic acid (EDTA) prepared in $50 \mathrm{mM}$ sodium citrate buffer ( $\mathrm{pH}$ 3.6). The reaction was stopped by adding $400 \mu \mathrm{L}$ of a revelation solution (43.8 mM 3,5-dinitrosalicyclic acid, $0.4 \mathrm{M} \mathrm{NaOH}$, and $1.06 \mathrm{M}$ sodium/ potassium tartrate). Samples were incubated for $5 \mathrm{~min}$ at $95^{\circ} \mathrm{C}$, and the absorbance measured at $540 \mathrm{~nm}$. Data were displayed in $\mu \mathrm{g}$ of formed maltose per mg of proteins per hour.

\section{Sucrose synthesis}

Sucrose Synthase (SSs - EC 2.4.1.13) and Sucrose Phosphate Synthase (SPS - EC 2.4.1.14). The SSs and SPS activities were determined according to Kubo et al. (2001). An aliquot of $100 \mu \mathrm{L}$ of enzyme extract was mixed to $50 \mu \mathrm{L}$ of $0.05 \mathrm{M}$ Tris- $\mathrm{HCl}(\mathrm{pH} 7.5)$ containing $100 \mathrm{mM}$ UDP-glucose, $100 \mathrm{mM}$ fructose and $10 \mathrm{mM}$
$\mathrm{MgCl}_{2}$. The assay was conducted for $30 \mathrm{~min}$ at $25^{\circ} \mathrm{C}$ and terminated by adding $150 \mu \mathrm{L}$ of $1 \mathrm{~N} \mathrm{NaOH}$. A blank was prepared by adding $1 \mathrm{~N} \mathrm{NaOH}$ immediately after the onset of the assay. Afterwards, unreacted hexoses in the reaction mixture were destroyed by heating for $10 \mathrm{~min}$ at $100^{\circ} \mathrm{C}$. To determine the amount of synthesized sucrose, $3 \mathrm{~mL}$ of $0.15 \%$ anthrone in $13.7 \mathrm{M} \mathrm{H}_{2} \mathrm{SO}_{4}$ were added and the mixture was incubated for $20 \mathrm{~min}$ at $40^{\circ} \mathrm{C}$. The SS activity was calculated as the increase of absorbance at $620 \mathrm{~nm}$, and the data were expressed in $\mu \mathrm{g}$ of formed sucrose per mg of proteins per hour. SPS was assayed following the same protocol than SS, except that fructose was replaced to fructose-6-phosphate.

\section{Sucrose degradation}

Sucrose Synthase (SSd - EC 2.4.1.13) - The SS cleavage activity was measured according to Kubo et al. [48]. An aliquot $200 \mu \mathrm{L}$ of enzyme source was mixed to $50 \mu \mathrm{L}$ of $0.05 \mathrm{M}$ Tris- $\mathrm{HCl}(\mathrm{pH} 7.5)$ containing $50 \mathrm{mM}$ sucrose. The reaction was performed for $30 \mathrm{~min}$ at $25^{\circ} \mathrm{C}$ and terminated by adding $250 \mu \mathrm{L}$ of $1 \mathrm{~N} \mathrm{NaOH}$. A blank was prepared by adding $1 \mathrm{~N} \mathrm{NaOH}$ at the onset of the assay. Afterwards, hexoses were destroyed by heating for $10 \mathrm{~min}$ at $100^{\circ} \mathrm{C}$ and an aliquot $(50 \mu \mathrm{L})$ was used for sucrose determination using the anthrone method described above. The SSd activity was measured as the decrease in absorbance of $620 \mathrm{~nm}$ and expressed in $\mu \mathrm{g}$ of degraded sucrose per $\mathrm{mg}$ of proteins per hour.

Acid invertase (EC 3.2.1.26) - Wall-bound and soluble acid invertase activities were measured according to the modified protocol of Dreier et al. [49]. The pellet of the enzyme extract was used for wall-bound invertase (WB Inv), whereas the supernatant was used for determining the cytosolic invertase (Cy Inv) activity. An aliquot of $100 \mu \mathrm{L}$ was mixed to $400 \mu \mathrm{L}$ with $0.2 \mathrm{M}$ acetate buffer ( $\mathrm{pH} 4.0$ ). The reaction was started by adding $800 \mu \mathrm{L}$ of $0.225 \mathrm{M}$ sucrose, extended for $30 \mathrm{~min}$ at $30^{\circ} \mathrm{C}$ and was stopped by adding $1 \mathrm{~mL}$ of DNSA-reagent (3,5-dinitrosalicylic acid 1\%), in $0.5 \mathrm{M} \mathrm{KOH}$ and $1 \mathrm{M} \mathrm{K} / \mathrm{Na}$-tartrate. Glucose $(0.5 \mu \mathrm{mol})$ was supplied to avoid oxygen interference at low reducing sugar concentrations and the mixture was boiled for $10 \mathrm{~min}$. After cooling, the invertase activity was calculated as the mean of absorbance at $560 \mathrm{~nm}$ and expressed in $\mu \mathrm{g}$ formed glucose per $\mathrm{mg}$ of proteins per hour. The vacuolar invertase activity was not assayed because not involved in the carbon metabolism of both male and female reproductive structures $[10,50]$.

\section{Data analysis}

For each stage of flower development, 5 assays were performed from five inflorescences of five different plants, and three independent readings were carried out. Each result was the mean \pm SE of these data. Mean comparison was carried out using Student's t-test, and difference was considered as significant at the $\mathrm{P}=0.05$ level.

\section{Results \\ Carbohydrates}

Globally starch fluctuated similarly in the GW and the PN inflorescences, with a global decrease during the flower development. Nevertheless, some remarkable differences can be noticed, especially from DS2 to DS4, and at DS7 (Figure 1a). During the period of both male and female meiosis (DS2 to DS4), starch level decreased in 
both cvs., but remained higher (around 2 fold at DS3) in GW than in PN until DS4 (5.0 $\pm 0.4 \%$ DW in GW and $3.9 \pm 0.3 \%$ DW in PN). Afterwards, a wave of amylogenesis/amylolysis was detected in the inflorescences of both cvs. With a higher amount of starch in GW (6.2 $\pm 0.5 \% \mathrm{DW}$ in GW and $4.3 \pm 0.2 \% \mathrm{DW}$ in PN) at flower bloom (DS7). Sucrose content fluctuated irregularly during the flower development in the two cvs. (Figure 1b). The sucrose content was relatively weak during the whole development in the two cvs. (Less than $4 \%$ DW), sometimes closed to $0 \%$ of dry weight (DS2 and DS3 in PN or DS5 in GW). Nevertheless, at DS3, inflorescences exhibited a peak of sucrose in PN $(7.1 \pm 4.1 \% \mathrm{DW})$ and GW $(16.6 \pm 1.1 \% \mathrm{DW})$. The sucrose level decreased afterwards, then remained low until the fruit set.

\section{Starch synthesis}

The rate of starch synthesis in inflorescences was evaluated by assaying StSy activity during the flower development (Figure 2a). In both GW and PN cvs., the StSy activity was in a range of $0.085 \mu \mathrm{g}$ formed amylose.mg protein ${ }^{-1} \cdot \mathrm{h}^{-1}$ at DS1, then decreased by $70 \%$ at DS2. Afterwards, the pattern of activity varied according to the cv. Thus, in GW, the activity fluctuated in accordance with the starch degradation, remained around $0.02 \mu \mathrm{g}$ formed amylose.mg protein ${ }^{1} . h^{-1}$ until DS4, then increased to reach a peak at DS6 $(0.08 \mu \mathrm{g}$ formed amylose.mg protein $\left.{ }^{-1} \cdot \mathrm{h}^{-1}\right)$ followed by a slight decrease $(0.06 \mu \mathrm{g}$ formed amylose.mg protein ${ }^{-1} \cdot h^{-1}$ at DS8). In PN, the variation of StSy

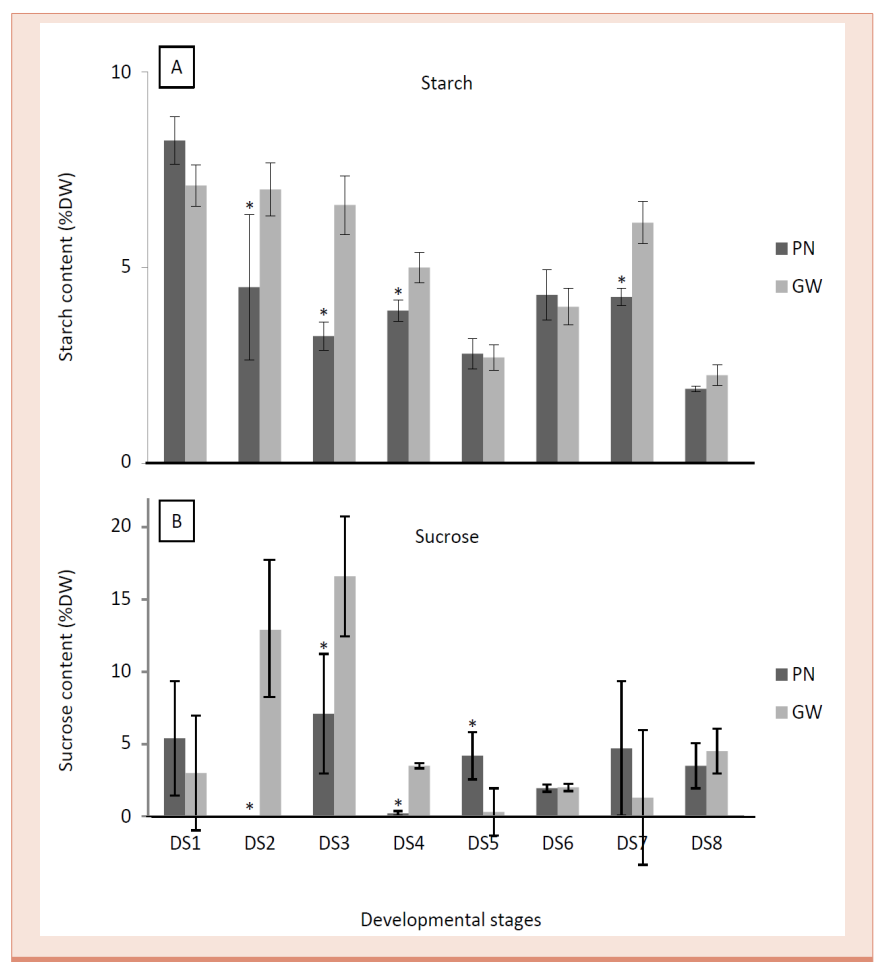

Figure 1: Changes in starch $(A)$ and sucrose $(B)$ contents of the $P N$ and GW cVs. inflorescences during flower development. Values are means $( \pm \mathrm{SE})$ of 5 measurements performed at "visible cluster" stage (DS1), "separated cluster" stage (DS2), 2 and 8 days after "separated cluster" stage (DS3 and 4), "flower separating" stage (DS5), "first detached floral caps" stage (DS6), 80\% "fallen flowerhoods" stage (DS7) and "fruit set" stage (DS8). Statistical analyses were carried out using Student's t-test. For each stage, a $5 \%$ probability was considered significant and marked by an asterisk.

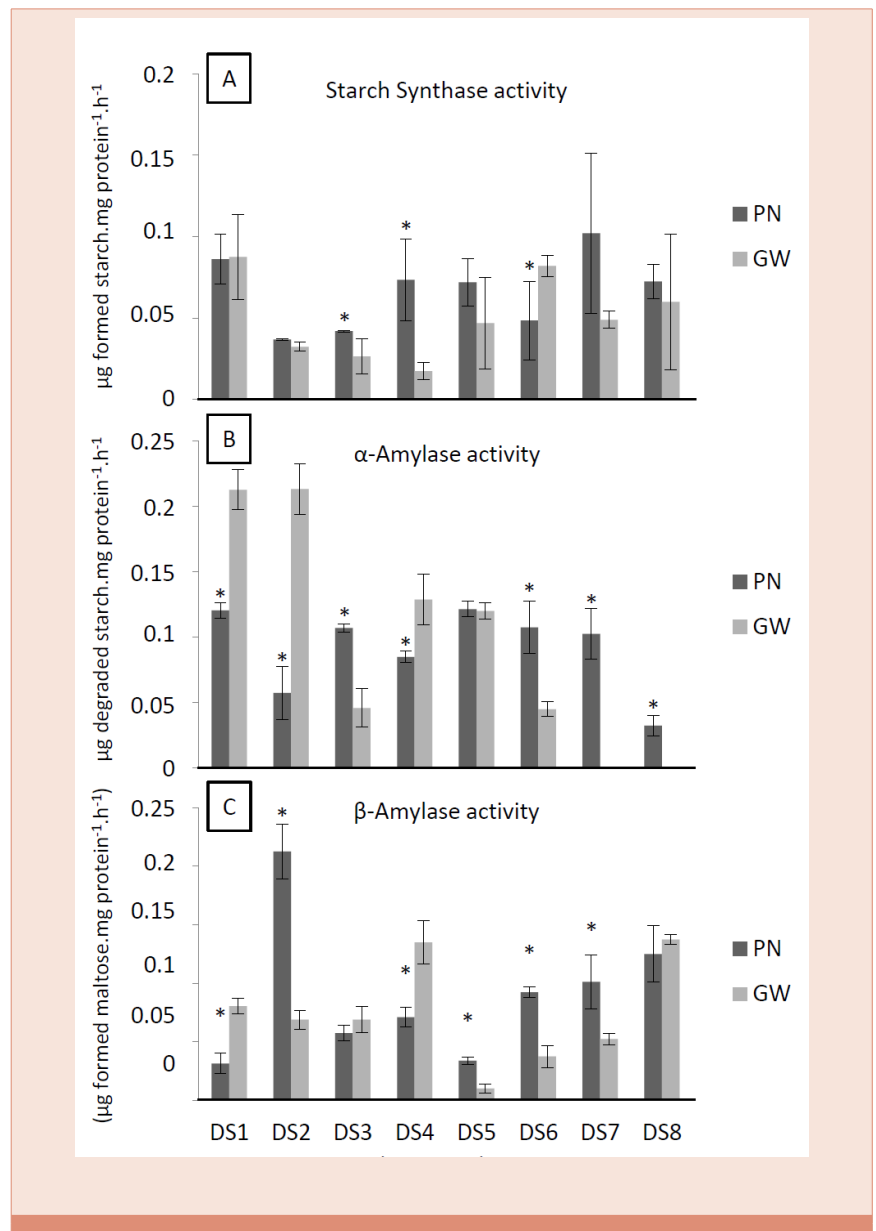

Figure 2: Changes in Starch Synthase (A), $\alpha$-amylase (B) and $\beta$-amylase (C) activities in inflorescences of Pinot Noir and Gewurztraminer during the flower development. Values are means $( \pm S E)$ of 5 measurements performed at "visible cluster" stage (DS1), "separated cluster" stage (DS2), 2 and 8 days after "separated cluster" stage (DS3 and 4), "flower separating" stage (DS5), "first detached floral caps" stage (DS6), 80\% "fallen flower hoods" stage (DS7) and "fruit set" stage (DS8). Statistical analyses were carried out using Student's t-test. For each stage, a $5 \%$ probability was considered significant and marked by an asterisk.

activity also corresponded to starch fluctuations in the inflorescence (Figure 1a). The activity increased up to $0.07 \mu \mathrm{g}$ formed amylose.mg $\operatorname{protein}^{-1} \cdot \mathrm{h}^{-1}$ at DS4, and remained stable until the fruit set (Figure 2a).

\section{Starch degradation}

Both amylases displayed noticeable differences between the two cvs. In term of fluctuations during the flower development (Figure 2b,c) but correlated well with variations measured in starch degradation/synthesis (Figure 1a). In GW, the aA activity globally coincided with starch variations (Figure $2 b$ ). The highest was reached at DS1 and DS2, ranging $0.21 \mu \mathrm{g}$ of hydrolysed starch.mg protein ${ }^{-1} \cdot \mathrm{h}^{-1}$. The level transitory fell to $0.05 \mu \mathrm{g}$ of hydrolysed starch.mg protein ${ }^{1} \cdot h^{-1}$ at DS3. Then, a new peak of the enzyme activity was registered during DS4 and DS5. Finally, the aA activity decreased until being detectable during the two last developmental stages. In $\mathrm{PN}$, the $\mathrm{aA}$ activity poorly fluctuated as the starch content in inflorescences. It was ranging approximately $0.1 \mu \mathrm{g}$ of hydrolyzed starch.mg protein 
${ }^{1} \cdot \mathrm{h}^{-1}$ from DS1 to DS7, despite it slightly diminished at DS2. A significant decrease was finally registered $(0.03 \mu \mathrm{g}$ of hydrolyzed starch.mg protein $\left.{ }^{-1} \cdot \mathrm{h}^{-1}\right)$ at DS8.

The $\beta \mathrm{A}$ activity (Figure $2 \mathrm{c}$ ), as for $\alpha \mathrm{A}$ activity, was in accordance with the pattern of starch fluctuations in inflorescences of the two cvs. (Figure 1a). In GW, the $\beta \mathrm{A}$ activity was constant between DS1 and DS3 (around $0.08 \mu \mathrm{g}$ of formed maltose.mg protein ${ }^{-1} \cdot \mathrm{h}^{-1}$ ) where the starch concentration did not fluctuate. A peak reaching $0.14 \mu \mathrm{g}$ of formed maltose.mg protein ${ }^{-1} \cdot \mathrm{h}^{-1}$ was observed at DS4, corresponding to the onset of starch hydrolysis. The activity was then declined between DS5 and DS7 whereas it increased at DS8 to reach $0.14 \mu \mathrm{g}$ of formed maltose.mg protein ${ }^{-1} \cdot \mathrm{h}^{-1}$, in parallel with starch degradation. In $\mathrm{PN}$, a huge peak reaching $0.21 \mu \mathrm{g}$ formed maltose.mg protein ${ }^{-1} \cdot \mathrm{h}^{-1}$ was detected at DS1, corresponding to the simultaneous strongest mobilization of starch. Afterwards, the activity was not significantly modified until DS5, then slowly increased until fruit set $(0.13 \mu \mathrm{g}$ of formed maltose.mg protein $\left.{ }^{-1} \cdot h^{-1}\right)$, in accordance with starch degradation.

\section{Sucrose synthesis}

The SPS activity had the same pattern during the flower development in the both cvs. (Figure 3a) and was poorly correlated to sucrose variations (Figure $1 b$ ). The SPS activity was quite constant during the development, ranging approximately at $0.15 \mu \mathrm{g}$ formed sucrose mg.protein ${ }^{-1} \cdot h^{-1}$. A temporary increase, by 3 and 6 fold in GW and $\mathrm{PN}$ respectively, was noticed at DS6.

The SSs activity had different patterns in the two cvs. (Figure 3b). While no activity was measured at DS1, DS5, DS7, and DS8 in GW, a huge peak $\left(0.172 \pm 0.050 \mu \mathrm{g}\right.$ formed sucrose mg.protein $\left.{ }^{-1} \cdot \mathrm{h}^{-1}\right)$ was registered at DS2, corresponding to a simultaneous increase of sucrose concentrations (Figure 1b). In PN, the SSs activity was 0.167 $\pm 0.020 \mu \mathrm{g}$ formed sucrose.mg protein ${ }^{-1} \cdot \mathrm{h}^{-1}$ at the onset of flower development. Then, it declined during the following steps until DS3, which could be correlated with a decreased of sucrose contents (Figure 1b). At DS4, a peak of the SSs activity $(0.140 \pm 0.018 \mu \mathrm{g}$ formed sucrose.mg protein $\left.{ }^{-1} \cdot \mathrm{h}^{-1}\right)$, followed by a significant increase of sucrose content (Figure $1 \mathrm{~b}$ ). Thereafter, the SSs activity slightly diminished and was completely nil at DS8.

\section{Sucrose degradation}

The sucrose cleavage was assayed by measuring activities of SSd (Figure 3c), WB Inv (Figure 3d), and Cy Inv (Figure 3e). The SSd activity fluctuated oppositely to sucrose content in both cultivars (Figure 3c). In GW, the SSd activity declined by $75 \%$ between DS1

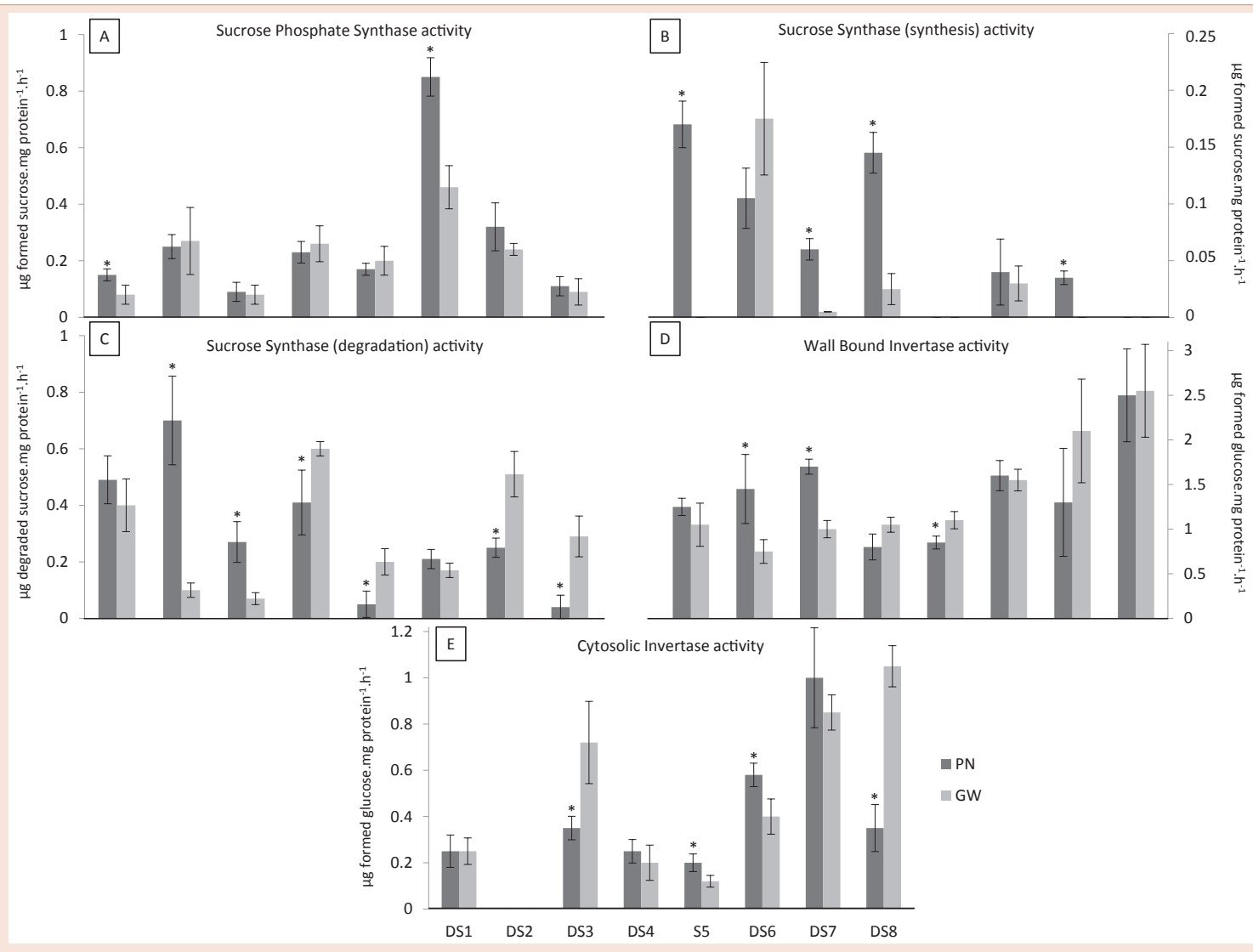

Figure 3: Changes in Sucrose Phosphate Synthase (A), Sucrose Synthase "synthesis" (B), Sucrose Synthase "degradation" (C), Wall-Bound Invertase (D) and Cytosolic Invertase $(E)$ activities in inflorescences of Pinot Noir and Gewurztraminer during the flower development. Values are means ( \pm SE) of 5 measurements performed at "visible cluster" stage (DS1), "separated cluster" stage (DS2), 2 and 8 days after "separated cluster" stage (DS3 and 4), "flower separating" stage (DS5), "first detached floral caps" stage (DS6), 80\% "fallen flowerhoods" stage (DS7) and "fruit set" stage (DS8). Statistical analyses were carried out using Student's t-test. For each stage, a $5 \%$ probability was considered significant and marked by an asterisk. 
$\left(0.4 \pm 0.09 \mu \mathrm{g}\right.$ degraded sucrose mg.protein $\left.{ }^{-1} \cdot \mathrm{h}^{-1}\right)$ and DS3 $(0.07 \pm$ $0.02 \mu$ g degraded sucrose mg.protein $\left.{ }^{-1} \cdot \mathrm{h}^{-1}\right)$, whereas the sucrose was accumulated in the meantime (Figure 1b). A peak of the SSd activity was registered at DS4, reaching $0.60 \pm 0.02 \mu \mathrm{g}$ degraded sucrose mg.protein ${ }^{-1} \cdot \mathrm{h}^{-1}$, concomitantly with a sucrose degradation. A second peak $\left(0.51 \pm 0.08 \mu \mathrm{g}\right.$ degraded sucrose $\mathrm{mg}$. protein $\left.^{-1} \cdot \mathrm{h}^{-1}\right)$ was finally observed at DS7. In PN inflorescences, the SSd activity presented two peaks at DS1 and DS4, corresponding respectively to $0.71 \pm 0.16$ and $0.42 \pm 0.11 \mu \mathrm{g}$ degraded sucrose.mg protein ${ }^{-1} \cdot \mathrm{h}^{-1}$ and coinciding with a weak sucrose content (Figure 1b). The activity of SSd in PN was parallel to the SSd activity observed in GW from DS5 to DS8 (Figure 3c).

The cleavage of sucrose by invertases may occur either in the cell wall (WB Inv) or in the cytosol (Cy Inv). The WB Inv activity poorly fluctuated during the inflorescence development (Figure 3d). In GW, the activity was effective but constant, ranging approximately at $1 \mathrm{mg}$ degraded sucrose.mg protein ${ }^{-1} \cdot \mathrm{h}^{-1}$, from DS1 to DS5, then progressively increased up to $2.55 \pm 0.52 \mu \mathrm{g}$ degraded sucrose. mg protein ${ }^{-1} \cdot h^{-1}$ at DS8. Similar variation was observed in PN inflorescence. The WB Inv activity in PN did not coincide with the sucrose content at DS2 (Figure 1b).

The Cy Inv activity was lower than WB Inv and had globally similar patterns in the two cvs. (Figure 3e). The Cy Inv activity was not really correlated with the sucrose content variations except at DS3 (Figure 1b). At that time, the Cy Inv activity showed a temporary peak, reaching respectively $0.72 \pm 0.17$ and $0.35 \pm 0.05 \mu \mathrm{g}$ degraded sucrose. $\mathrm{mg}$ protein $^{-1} \cdot \mathrm{h}^{-1}$ in GW and $\mathrm{PN}$. The Cy Inv activity progressively increased until from DS5 to the onset of fruit development, reaching the highest values at DS7 in PN $(1.03 \pm 0.22 \mu$ g degraded sucrose.mg protein $\left.^{-1} \cdot \mathrm{h}^{-1}\right)$ and DS8 in GW $(1.05 \pm 0.09 \mu \mathrm{g}$ degraded sucrose.mg protein $\left.^{-1} \cdot \mathrm{h}^{-1}\right)$. In PN inflorescences, the Cy Inv decreased to $0.35 \pm$ $0.10 \mu \mathrm{g}$ degraded sucrose.mg protein ${ }^{-1} \cdot \mathrm{h}^{-1}$ at DS8.

\section{Discussion}

In grapevine inflorescences, both the development of reproductive organs and the carbohydrate metabolism are different in the flowerabscission sensitive GW and the non-sensitive PN. Indeed, the ontogenesis of reproductive organs is not synchronous in GW and $\mathrm{PN}$ cvs. Since both female and male meiosis occurred earlier in PN than in GW [1].

Starch and sucrose related enzyme activities were assayed in grapevine inflorescences during the development of flower growing in the vineyard for the first time. Our results showed that carbohydrate contents evolved during the development in the two cvs. In general, starch content decreased slowly and continually whereas the sucrose content increased through the first steps of the flower development before a decrease starting from the beginning of the flowering process.

In both cvs., the starch level variations were closely correlated with both enzyme activities. In GW inflorescences, the starch content was not really linked to the StSy activity but it was concomitant with the $\alpha$-amylase activity and inversely linked to the $\beta$-amylase activity during the four first steps, then a tendency reversal occurred. The situation is different in PN since the variation of starch content was closely associated with enzyme activities, except with the $\beta$-amylase activity at DS2. Our results are in accordance with earlier results obtained in maize. Indeed, fluctuations of the starch content in maize ovaries are strongly related to the total amylase activity from 5 days before pollination to 2 days after [51]. Moreover, it was already noticed that the starch content in PN could be correlated with the StSy activity in contrast to GW, leading the authors to suggest that although a similar starch concentration, the regulation of starch synthesis was different in inflorescences of the two cvs. Obtained from the artificial fruiting cutting model [26].

In both cvs., fluctuations of the sucrose in inflorescences during the flower development is consistent with activities of the three tested sucrose degradation enzymes, with a better correlation in PN. Indeed, fluctuations in the sucrose content were coherent with the SSd activity. In GW and PN inflorescences, each increase/decrease of the SSd activity coincided with a decrease/increase of the sucrose level. Moreover, the continual increase of Cy Inv and WB Inv activities during the last steps of the flower development also coincided with the low sucrose content in inflorescences of both cvs. In rice and wheat anthers, the SSd activity, except in wheat at the anthesis where the stimulation of SSd activity induces a strong decrease of sucrose levels [52]. In grapevine, Sawicki et al. [26], already noticed a better correlation between activities of sucrose degradation enzymes and sucrose content in PN, compared to GW. These authors suggested that the higher degradation of sucrose in $\mathrm{PN}$ inflorescence around the female meiosis stage induced higher contents of hexose.

In the inflorescence of both cvs., activities of sucrose synthesizing enzymes do not have the same influence. Indeed, the SPS activity does not seem to interfere with sucrose variations, as well as in leaves of wheat [53]. Nevertheless, the SSs activity might act in synergy with lower activities of sucrose degrading enzymes (SSd, invertases) during the first steps of development in GW inflorescences, explaining the sucrose increase observed at the beginning of "separated cluster" stage in this cultivar.

It appeared that in grapevine inflorescences, the sucrose was more degraded from the "flower separating" stage. Our results exhibit a significant enhance of both invertase (Cy and WB) activities at this stage. Moreover, at the "flower separating" stage, the chlorophyll concentration regularly diminishes leading to a decrease of net $\mathrm{CO}_{2}$ assimilation and to the arrest of net positive photosynthesis at the fruit set for both GW and PN inflorescences [16,54,]. In the grapevine, during the flower development, inflorescences import carbohydrates and export photoassimilates [25]. Consequently, sugar contents fluctuate differently according to the metabolism of the cultivar and inflorescences become a sink for carbohydrates from BBCH57 stage. It was already reported that the leaf photosynthetic rates are lower in GW than in PN [41] and that inflorescences have shown fluctuations in the photosynthetic activity during the flower development $[6,26,27]$.

In grapevine, the accumulation of carbohydrates in berries begins during the maturation (Mullins et al. 1992). The sucrose is thus hydrolyzed, leading to an equal concentration in glucose and fructose $[55,56]$. It has been demonstrated that the activity of sucrose degrading enzymes in berry is stimulated at the fruit set and further increases until veraison $[55,57]$. In accordance, our results exhibit an 
increase in Cy Inv and WB Inv activities from the flowering till the fruit set.

During the flower development, variations of inflorescence enzyme activities between GW and PN can be connected with their differences in sugar contents. Indeed, the pool of available hexoses in developing inflorescences is higher in the PN than in the GW [1]. Moreover, differences observed in the regulation of both cvs. May explain the lower sensitivity to flower abscission in PN under stress conditions $[1,18]$ and the higher fruit set in GW under optimal conditions [26]. Finally, the significant increase of sucrose degrading enzyme activities such as SSd, Cy Inv, and WB Inv during the last steps of the flower development may be interpreted as the first sign of the strong physiological modifications that occurs in the ovaries between the fertilization and the onset of fruit formation. This transition is reflected by both the positive photosynthesis in the inflorescence [16] and the early development of berries [58-60].

\section{Acknowledgements}

The authors would like to acknowledge the Conseil Interprofessionnel du Vin de Bordeaux, ONIVINS, Mumm-PerrierJouët Company and Reims métropole for their financial supports.

\section{References}

1. Lebon G, Duchêne E, Brun O, Magné C, Clément C (2004) Flower abscission and inflorescence carbohydrates in sensitive and non-sensitive cultivars of grapevine. Sex Plant Reprod 17: 71-79.

2. Huglin P, Schneider C (1998) Biologie et écologie de la vigne, 2nd edn. Lavoisier Tech Doc, Paris.

3. Sawicki M, Aït Barka E, Clément C, Vaillant-Gaveau N, Jacquard C (2015a) Cross-talk between environmental stresses and plant metabolism during reproductive organ abscission. J. Exp. Bot 66: 1707-1719.

4. Ebadi A, May P, Coombe BG (1996) Effect of short-term temperature and shading on fruit-set, seed and berry development in model vines of Vitis vinifera, cvs Chardonnay and Shiraz. Austr J Grape Wine Res 2: 2-9.

5. Sawicki M, Jeanson E, Celiz V, Clément C, Jacquard C, et al. (2012) Adaptation of grapevine flowers to cold involves different mechanisms depending on stress intensity. PLoS One 7: e46976.

6. Sawicki M, Aït Barka E, Clément C, Gilard F, Tcherkez G, et al. (2015c) Coldnight responses in grapevine inflorescences. Plant Sci 239: 115-127.

7. Greer DH, Weston C (2010) Heat stress affects flowering, berry growth, sugar accumulation and photosynthesis of Vitis vinifera cv. Semillon grapevines grown in a controlled environment. Funct Plant Biol 37: 206-214.

8. Dry PR, Longbottom ML, Mcloughlin S, Johnson TE, Collins C (2010) Classification of reproductive performance of ten winegrape varieties. Aust $J$ Grape Wine R 16: 47-55.

9. Yu TS, Lue WL, Wang SM, Chen J (2000) Mutation of Arabidopsis plastid phosphoglucose isomerase affects leaf starch synthesis and floral initiation. Plant Physiol, 12: 319-326.

10. Dorion S, Lalonde S, Saini HS (1996) Induction of male sterility in wheat by meiotic-stage water deficit is preceded by a decline in invertase activity and changes in carbohydrate metabolism in anthers. Plant Physiol 111: 137-145.

11. Jean D, Lapointe L (2001) Limited carbohydrate availability as a potential cause of fruit abortion in Rubus chamaemorus. Physiol Plant 112: 379-387.

12. Prymakowska-Bosak M, Przewloka MR, Slusarczyk J, Kuras M, Lichota J, et al. (1999) Linker histones play a role in male meiosis and the development of pollen grains in tobacco. Plant Cell 11: 2317-2329.
13. Siddiqi I, Ganesh G, Grossniklaus U, Subbiah V (2000) The dyad gene is required for progression through female meiosis in Arabidopsis. Development 127: 197-207.

14. Pego JV, Kortstee AJ, Huijser C, Smeekens SCM (2000) Photosynthesis, sugars and the regulation of gene expression. J Exp Bot 51: 407-416.

15. Paul MJ, Pellny TK, Goddijn O (2001) Enhancing photosynthesis with sugar signals. Trends Plant Sci 6: 197-200.

16. Lebon G, Brun O, Magné C, Clément C (2005a) Photosynthesis of the grapevine (Vitis vinifera L.) inflorescence. Tree Physiol 25(5): 633-639.

17. Zapata C, Deléens E, Chaillou S, Magné C (2004a) Partitioning and mobilization of starch and $\mathrm{N}$ reserves in grapevine (Vitis vinifera L.). J Plant Physiol, 161: 1031-1040.

18. Zapata C, Deléens E, Chaillou S, Magné C (2004b) Mobilisation and distribution of starch and total $\mathrm{N}$ in two grapevine cultivars differing in their susceptibility to shedding. Funct Plant Biol, 31: 1127-1135.

19. Ainsworth EA, Bush DR (2011) Carbohydrate export from the leaf: a highly regulated process and target to enhance photosynthesis and productivity. Plant Physiol 155: 64-69.

20. Lecourieux F, Kappel C, Lecourieux D, Serrano A, Torres E, et al. (2014) An update on sugar transport and signalling in grapevine. J Exp Bot 65: 821-832.

21. Nakamura Y, Yuki K (1992) Changes in enzyme activities associated with carbohydrate metabolism during the development of rice endosperm. Plant Sci 82: 15-20.

22. Sturm A, Tang GQ (1999) The sucrose-cleaving enzymes of plants are crucial for development, growth and carbon partitioning. Trends Plant Sci 4: 401-407.

23. Salerno GL, Curatti L (2003) Origin of sucrose metabolism in higher plants: when, how and why? Trends Plant Sci 8: 63-69.

24. Vanden Heuvel JE, Leonardos ED, Proctor JTA, Fisher KH, Sullivan JA (2002) Translocation and partitioning patterns of $14 \mathrm{C}$ photoassimilate from light- and shade-adapted shoots in greenhouse-grown 'Chardonnay' grapevines (Vitis vinifera L.). J Am Soc Hort Sci 127: 912-918.

25. Vaillant-Gaveau N, Maillard P, Wojnarowiez G, Gross P, Clément C, et al. (2011) Inflorescence of grapevine (Vitis vinifera L.): a high ability to distribute its own assimilates. J Exp Bot 62: 4183-4190.

26. Sawicki M, Jacquens L, Baillieul F, Clément C, Vaillant-Gaveau N, et al (2015b) Distinct regulation in inflorescence carbohydrate metabolism according to grapevine cultivars during floral development. Physiol Plant 154: 447-467.

27. Sawicki M, Courteaux B, Rabanoelina F, Baillieul F, Clément C, et al. (2016) Leaf vs inflorescence: differences in photosynthetic activity of grapevine. Photosynthetica 2016.

28. Rodrigo J, Herrero M (1998) Influence of intraovular reserves on ovule fate in apricot (Prunus armeniaca L.). Sex Plant Reprod 11: 86-93.

29. Rolland F, Baena-Gonzalez E, Sheen J (2006) Sugar sensing and signaling in plants: conserved and novel mechanisms. Annu Rev Plant Biol 57: 675709.

30. Zeeman S, Smith S, Smith A (2007) The diurnal metabolism of leaf starch Biochema J 401: 13-28.

31. Yu TS, Zeeman SC, Thorneycroft D, Fulton DC, Dunstan H, et al. (2005) a-Amylase is not required for breakdown of transitory starch in Arabidopsis leaves. J Biol Chem 280: 9773-9779.

32. Lloyd JR, Kossmann J, Ritte G (2005) Leaf starch degradation comes out of the shadows. Trends Plant Sci 10: 130-137.

33. Mukerjea R, Robyt JF (2005) Starch biosynthesis: the primer nonreducingend mechanism versus the nonprimer reducing-end two-site insertion mechanism. Carbo Res 340:245-255.

34. Zeeman S, Kossmann J, Smith A (2010) Starch: Its metabolism, Evolution, and biotechnological Modification in Plants. Annu Rev Plant Biol 61: 209-234. 
35. Lalonde S, Wipf D, Frommer WB (2004) Transport mechanisms for organic forms of carbon and nitrogen between source and sink. Annu Rev Plant Biol 55: $341-372$

36. Lemoine R, La Camera S, Atanassova R, Dédaldéchamp F, Allario T, et al (2013) Source-to-sink transport of sugar and regulation by environmental factors. Front Plant Sci 4: 272.

37. Huber SC, Huber JL (1996) Role and regulation of sucrose-phosphate synthase in higher plants. Annu Rev Plant Physiol Plant Mol Biol 47: 431-444.

38. Wang HL, Lee PD, Chen WL, Huang DJ, Su JC (2000) Osmotic stressinduced changes of sucrose metabolism in cultured sweet potato cells. J Exp Bot 51: 1991-1999.

39. Miller WB, Ranwala AP (1994) Characterization of three soluble invertase forms from Lilium longiflorum flower buds. Physiol Plant 92: 247-253.

40. Dejardin A, Rochat C, Wuilleme S, Boutin JP (1997) Contribution of sucrose synthase, ADP-glucose pyrophosphorylase and starch synthase to starch synthesis in developing pea seeds. Plant Cell Environ 20: 1421-1430.

41. Lebon G, Duchêne E, Brun O, Clément $C$ (2005b) Phenology of flowering and starch accumulation in grape (Vitis vinifera L.) cuttings and vines. Ann Bot (Lond) 95: 943-948.

42. Glad C, Regnard JL, Querou Y, Brun O, Morot-Gaudry JF (1992) Flux and chemical composition of xylem exudates from Chardonnay grapevines: temporal evolution and effect of recut. Am J Enol Vitic 43: 275-282.

43. Meier U (2001) Growth stages of mono-and dicotyledonous plants. BBCH monograph. German federal biological research centre for agriculture and forestry, Berlin.

44. Bergmeyer HU (1974) Methods of enzymatic analysis. Verlag Chemie, Weinheim Basel.

45. Nakamura Y, Yuki K, Park S, Ohya T (1989) Carbohydrate metabolism in the developing endosperm of rice grains. Plant Cell Physiol 30: 833-839.

46. Salas E, Cardemil L (1986) The multiple forms of? -amylase enzyme of the Araucaria species of South America: Araucaria araucana (Mol.) Koch and Araucaria angustifolia (Bert) O. Kutz. Plant Physiol 81: 1062-1068.

47. Okamoto K, Akazawa T (1979) Enzymic mechanism of starch breakdown in germinating rice seeds. 8. Immunohistochemical localization of ? -amylase. Plant Physiol 64: 337-340.

48. Kubo T, Hohjo I, Hiratsuka S (2001) Sucrose accumulation and its related enzyme activities in the juice sacs of Satsuma mandarin fruit from trees with different crop loads. Sci Hortic 91: 215-225.
49. Dreier LP, Hunter JJ, Ruffner HP (1998) Invertase activity, grape berry development and cell compartmentation. Plant Physiol Biochem 36(12): 865872.

50. Sheoran IS, Saini HS (1996) Drought-induced male sterility in rice: changes in carbohydrate levels and enzyme activities associated with the inhibition of starch accumulation in pollen. Sex Plant Reprod 9: 161-169.

51. Zinselmeier C, Jeong BR, Boyer JS (1999) Starch and the control of kernel number in maize at low water potentials. Plant Physiol, 121: 25-36.

52. Yang J, Zhang J, Wang Z, Xu G, Zhu Q (2004) Activities of key enzymes in sucrose-to-starch conversion in wheat grains subjected to water deficit during grain filling. Plant Physiol 135: 1621-1629.

53. Savitch LV, Harney T, Huner NPA (2000) Sucrose metabolism in spring and winter wheat in response to high irradiance, cold stress and cold acclimation. Physiol Plant 108: 270-278.

54. Palliotti A, Cartechini A (2001) Developmental changes in gas exchange activity in flowers, berries, and tendrils of field-grown Cabernet Sauvignon. Am J Enol Vitic 52: 317-323.

55. Takayanagi T, Yokotsuka K (1997) Relationship between sucrose accumulation and sucrose-metabolizing enzymes in developing grapes. Am J Enol Vitic 48(4): 403-407.

56. Vignault C, Vachaud M, Cakir B, Glissant D, Dedaldechamp F, et al. (2005) VvHT1 encodes a monosaccharide transporter expressed in the conducting complex of the grape berry phloem. J Exp Bot 56: 1409-1418.

57. Dai ZW, Léon C, Feil R, Lunn JE, Delrot S, et al. (2013) Metabolic profiling reveals coordinated switches in primary carbohydrate metabolism in grape berry (Vitis vinifera L.), a non-climacteric fleshy fruit. J Exp Bot 64: 13451355.

58. Mullins MG, Bouquet A, Williams LE (1992) Biology of the grapevine, Mullins (Ed), University Press, Cambridge, UK, 239.

59. Ali K, Maltese F, Fortes AM, Pais MS, Choi YH, et al. (2011) Monitoring biochemical changes during grape berry development in Portuguese cultivars by NMR spectroscopy. Food Chem 124: 1760-1769.

60. Martínez-Esteso MJ, Sellés-Marchart S, Lijavetzky D, Pedreño MA, BruMartínez R (2011) A DIGE-based quantitative proteomic analysis of grape berry esh development and ripening reveals key events in sugar and organic acid metabolism. J Exp Bot 62: 2521-2569.

61. Eichhorn KW, Lorenz DH (1977) Phöenologische Entwicklungsstadie. Der rebe. Nachrichtenb. Deutsch Pflanzenschutzd (Braunschweig) 29: 119-120.

62. Ruiz R, Garcia-Luis A, Honerri C, Guardiola JL (2001) Carbohydrate availability in relation to fruitlet abscission in Citrus. Ann Bot (Lond) 87: 805812.

Copyright: (c) 2016 Lebon G, et al. This is an open-access article distributed under the terms of the Creative Commons Attribution License, which permits unrestricted use, distribution, and reproduction in any medium, provided the original author and source are credited. 